under the title, "On the Way to Inhabited Space", reviews the demands likely to be made on science by the investigation and the conquest of space, including a thorough discussion of life in space and the design of space suits. An article by S. Ezratty, "Television and Society", after reviewing briefly the development of television, considers the practical uses of television and the impact television has so far had on society. He concludes that so far the impact has been disappointing and the potentialities have not been realized. In E. D. Howe's article, "The Demineralization of Water", the present position of desalination is reviewed, particularly in the United States. Very large distillation plants, combined with nuclear-fuelled steam-power plants, promise to give comparatively lowcost potable water at an early date. In addition, further developments of the new process of electrodialysis, of freeze-separation, and of reverse osmosis could lead to further reductions in the cost. In the fourth article, S. K. Bose, under the title "Technological Institutes: a New Dimension in Education in India", describes the organization and work of the Indian Institute of Technology at Bombay.

International Commission on Zoological Nomenclature

Notice is hereby given of the possible use by the International Commission on Zoological Nomenclature of its plenary powers in connexion with the following cases, full details of which will be found in the Bulletin of Zoological Nomenclature (22, Part 5/6; January 31, 1966). (758) Type-species for Zorilla Geoffroy, 1826 (Mammalia). (1564) Neotype for Acarus telarius Linnaeus, 1758 (Acarina). (1114) Cancellation of Opinion 92 in so far ats it deals with Calamaria Boie, 1827; validation of, and type-species for, Calamaria Boie, 1827: validation of Calamaria linnaei Schlegel, 1837; Ruling on priority to be accorded to works of Schlegel and Boie (Reptilia). (671) Emendation to Ancistrodon of Agkistrodon Beauvois, 1799 (Reptilia). (1718) Priority to Kassina Girard, 1853, over Hylambates Duméril, 1853 (Amphibia). (1719) Suppression of Conus americanus, C. guineensis, C. surinamensis, C. medusa, C. coffeae, C. costatus, C. niveus, $C$. oculatus Gmelin, 1791 (Gastropoda). (1722) Suppression of Anopheles africanus Theobald, 1901 (Insecta, Diptera). (1724) Validation of Acanthomys leucopus Gray, 1867 (Mammalia). (1725) Removal of homonymy of Chrysopinae in Neuroptera and Diptera. (1613) Type-species for Erbula Stål, 1873 (Insecta, Hemiptera). (1669) Type-species for Amplexizaphrentis Vaughan, 1906 (Anthozoa). (1727) Suppression of Astacus oreganus Randall, 1840 (Crustacea, Decapoda). (1728) Either, Declaration of Voluta mitra Linnaeus, 1758, as a junior objective synonym of $V$. episcopalis Linnaeus, 1758 , or, suppression of V. mitra (Gastropoda). (1729) Validation of Praeradiolites Douvillé, 1902 (Bivalvir). Any zoologist who wishes to comment on any of the foregoing cases should send comments in duplicate, citing case number, to the Secretary, International Commission on Zoological Nomenclature, c/o British Museum (Natural History), Cromwell Road, London, S.W.7, before July 31, 1966.

\section{New Perspectives in Insect Control}

ON April 30, 1965, the Australian Academy of Science held a symposium in Canberra on the subject of pest control with particular emphasis on the effects of pesticides on man and on wild life. This was apparently a fully attended conference, during which several experts declared their views. The subject was vigorously debated. The following resolution was passed: "That this symposium requests the Academy of Science to investigate the need for better facilities in Australia for gathering data on pesticide residues in crops, pastures, soil and water, and research on the toxicity and other biological effects of pesticides upon non-target species". This resolution embodies the fears and hopes of many others not only in Australia. In Britain, for example, the subject is constantly being raised and argued both in the national and technical Press. A useful account of the work of this symposium and of the papers presented has now been published (The Australian Journal of Science, 28, No. 6; December 1965. Australian and New Zealand Association for the Advancement of Science, Science House, 157 Gloucester Street, Sydney). In his introductory remarks, O. H. Frankel (C.S.I.R.O.) points the way: "New Perspectives in Insect Control is concerned with insects, with man, and their interactions. We shall discuss attempts by insects to interfere with what we regard as 'our' plants and animals, and with ourselves; and our attempts to control, to 'manage' this world of insects ... the successes and limitations of our reactions to these insects". In discharge of this theme, the following titles of papers presented at the symposium and published in this issue of the Journal will convey some idea of coverage of this vital subject: "Setting the Scene: Pest Control Past and Present", by D. F. Waterhouse (C.S.I.R.O.); "The PostWar Insecticides", by J. 'T. Snelson (Geigy Agricultural Chemicals); "Non-Target Effects: Man", by S. E. Wright (Pharmacy Department, University of Sydney); "The Philosophy of Pest Control", by P. Geier (C.S.I.R.O.); "Integrated Insect Control", by B. N. Smallman (Queen's University, Canada); "The Use of Sterile Insects for Their Own Destruction", by D.F. Waterhouse (C.S.I.R.O.); "Biological Control", by F. N. Ratcliffe (C.S.I.R.O.); "The Use of Pathogens in Insect Control", by M. F. Day (C.S.I.R.O.); "Pheromones and Insect Control", by B. P. Moore (C.S.I.R.O.); and "Selective Toxicity", by A. Albert (Australian National University). In his "Concluding Remarks", O. H. Frankel said regarding insecticides that ". . . the feelings of the meeting are expressed in the resolution which you carried unanimously ... there is a widespread anxiety about the effects of pesticide residues on man and on wildlife; and about the toxicity of pesticides upon species other than the one for which they are intended. ... many of the areas of knowledge which open the new perspectives in pest control are as yet in the exploratory stage. A great deal of new research can now be visualized which is certain to produce exciting scientific and economic results".

\section{Root Temperature and Plant Growth}

Sorr temperature affects the concentration of plant nutrients by influencing microbiological activity and the speed of chemical reaction; when the nutrients are not very mobile their absorption obviously depends on the extent of the root system and thus fertilizer application may compensate for low temperatures. But the relation. ships between root temperature and shoot growth are complex and difficult to determine experimentally, although it seems that warm-temperature species prefer higher root temperatures than temperate species. A survey of the present knowledge on the subject, with an extensive bibliography, entitled "Effects of Root Temperature on Plant Growth" by K. I. Nielsen and E. C. Humphries is given in Soils and Fertilizers $(29$, No. 1, 1 ; 1966). Root and shoot growth may vary independently according to environment, although each depends on the other, the root for carbohydrate and the shoot for water and minerals. The root relies on that carbohydrate not used by the shoot and hence root growth is closely related to the intensity of assimilation by the leaves. The size of the root system is not, however, a measure of its absorbing capacity or physiological activity. Low temperatures reduce water absorption on account of a decrease in protoplasm permeability and an increase in water viscosity, but water transport is impeded less than ion transport. 'The optimum temperature for root development and absorption of nutrients is $20^{\circ} \mathrm{C}$ for many plants but may vary with stage of development; this is lower than for tops; moreover, roots tolerate a narrower range 